\title{
Internal Accounting Control System Design based on Accounting
}

Yan Li

School of management, Wuhan University of technology, Wuhan, 430070, China

Keywords: accounting, internal controls, system design.

\begin{abstract}
With the shortcomings of enterprise in our country increasingly exposed in the management, in which the quality problem of accounting information is particularly prominent, and to improve the situation, one of the key factors is to strengthen the internal accounting control of the enterprise. Internal accounting control is an important subsystem, which refers to the unit in order to improve the quality of accounting information, to ensure the safety and integrity of the assets, also to ensure relevant laws, rules and regulations for carrying out the formulation and implementation of a series of control methods, measures and procedures. The research object of this article is in view of the accounting internal control system, based on the enterprise internal accounting control system of the general design idea, putting forward the overall design patterns ,which focus on enterprise internal accounting control system.
\end{abstract}

\section{Introduction}

Accounting information is enterprise economic activity information after collecting, processing, sorting, and classifying the output through accounting department. It is the recognized important basis to correctly reflect the operating results of the enterprise and the economic value. It is the core part of the system of accounting behaviour, the essence of which is a reflection of all kinds of interest relations. Internal users of accounting information are primarily managers of enterprises and management. With the expansion of enterprises, any individual cannot be very familiar with the whole situation of the enterprise. In order to avoid one-sided understanding, business operators need complete and effective accounting information to grasp the overall economic situation, to improve the efficiency of management, so the quality of accounting information is very important. Practice proves that good internal accounting control can find fraud in time, effectively reduce the negative impact of accounting information distortion.

This article will take the basic theory of internal control as a research starting point, through the analysis of the internal accounting control theory and the practice situation, to put forward the enterprise internal accounting control system design of the overall train of thought, and devised its general internal accounting control system after studying of enterprise accounting business as a case.

\section{Internal Control Theory Framework}

\section{Background investigation}

Currently, many companies in our country, there is a big problem about the accounting companies.Weaknesses in internal accounting controls mainly in the following areas:

Table 1: The proportion of survey

\begin{tabular}{|c|c|c|c|c|c|c|c|}
\hline Topic & \multicolumn{4}{|c|}{$\begin{array}{c}\text { The effectiveness of the implementation of } \\
\text { internal accounting control system }\end{array}$} & \multicolumn{3}{c|}{$\begin{array}{c}\text { Reasons for the failure of internal } \\
\text { accounting control system }\end{array}$} \\
\hline Property-ion & Invalid & General & better & best & $\begin{array}{c}\text { System } \\
\text { is imperfect }\end{array}$ & $\begin{array}{c}\text { Poor } \\
\text { leader-ship }\end{array}$ & $\begin{array}{c}\text { Poor } \\
\text { execution }\end{array}$ \\
\hline Nature of units & $\%$ & $\%$ & $\%$ & $\%$ & $\%$ & $\%$ & $\%$ \\
\hline $\begin{array}{c}\text { Chief } \\
\text { Enterprise }\end{array}$ & 5 & 56 & 35 & 4 & 51 & 28 & 21 \\
\hline $\begin{array}{c}\text { State-owned } \\
\text { enterprises }\end{array}$ & 9 & 43 & 34 & 14 & 52 & 30 & 18 \\
\hline Foreign & & & & & & & \\
\hline
\end{tabular}




\begin{tabular}{|c|c|c|c|c|c|c|c|}
\hline Enterprise-se & 14 & 40 & 43 & 3 & 57 & 29 & 14 \\
\hline $\begin{array}{c}\text { Private } \\
\text { Enterprise-se }\end{array}$ & 17 & 49 & 17 & 17 & 59 & 34 & 7 \\
\hline Total & 9 & 49 & 34 & 8 & 53 & 29 & 18 \\
\hline
\end{tabular}

(1) Lack of awareness of managers, internal accounting controls for the lack of attention;

(2)Construction of internal accounting control system is not perfect, unreasonable;

(3)Internal governance structure is not perfect, which affect the validity of the implementation of internal accounting controls;

(4)Business execution is not strictly for their internal accounting control system;

(5) System on Evaluation of internal accounting controls audit lags behind.

June 2002, the survey conducted by Renmin University of China regarding on internal accounting controls. Conducted a special investigation and statistics on 266 enterprises and institutions to the implementation of internal accounting controls reasons of failure of internal controls.

From the survey results, the survey unit effectiveness of internal accounting control system is generally less than 58\%.Imperfect internal accounting control system design is the main reason of the situation that internal accounting control system is not fully play its role, accounted for $53 \%$ of all respondents. The case in which the enterprise is the most serious.

System design is necessary based on the background of these investigations.

Theoretical analysis

From internal control theory was advanced, there is the big change both on the control theory and framework. After the development in the 1990s, internal control research has entered a new stage, in 1992, the Committee of sponsoring Organizations issued a report the overall internal control framework, the research achievements of the COSO report got the business owners, management, auditors and experts and scholars generally agreement and thus become the most authoritative theory of internal control.

The COSO report proposed an internal control overall framework consist of three control targets and five element, specifically is the efficiency and effect of business activities, the reliability of financial report and related laws and regulations to follow three control objectives, its form also includes five basic factors, as shown in the figure below.

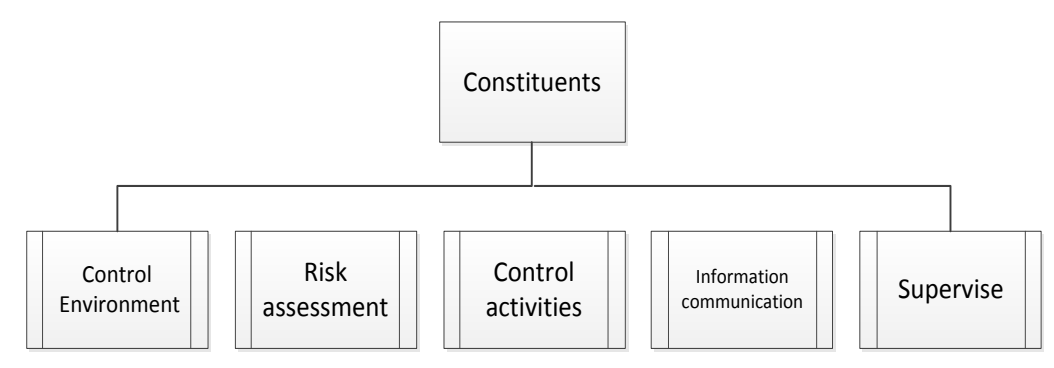

Fig.1 Internal control elements

Control environment: the core of any enterprise is the enterprise of the people and their activities, the activities of the people in the environment, the environment determines the atmosphere of an organization, influencing people in the organization's internal control consciousness. Control environment is the generic term of a group of factors that have a significant impact, such as establishment of the control of specific policies and enhance and effectively implement the floorboard of procedures.

Besides, risk assessment refers to the discrimination and analysis of various risks in the process of complete control target, thus providing basis for risk management. Control activity is to ensure management control goals to achieve and establish policies and procedures. Enterprises must adopt control and enforce policies and procedures to make management take the necessary action based on the risk in the process of control target for the enterprises to be completed. Information and communication system is the enterprise internal staff can get and exchange the required information in the process of enterprise management execution, management and control. Supervision is a kind of process as events through carrying out a performing quality evaluation system. 
Only by supervision, internal control system can make dynamic response varies with the change of situation.

These five factors are a mutual contact, the combination of the whole, they form the overall framework to reflect dynamic environment in the transformation.

\section{Internal Control System Design}

China's relevant departments have begun to pay attention to the construction of internal accounting controls, proposes six principles of internal accounting control system design: the legality, validity, comprehensiveness, mutually exclusive positions separated from each other, costeffective and timeliness since the 1990s.

Internal accounting control system design is a systematic project, it is necessary to take the general requirements of commonality into account, but also reflect the personality of the special requirements of the enterprise, its design steps as shown below:

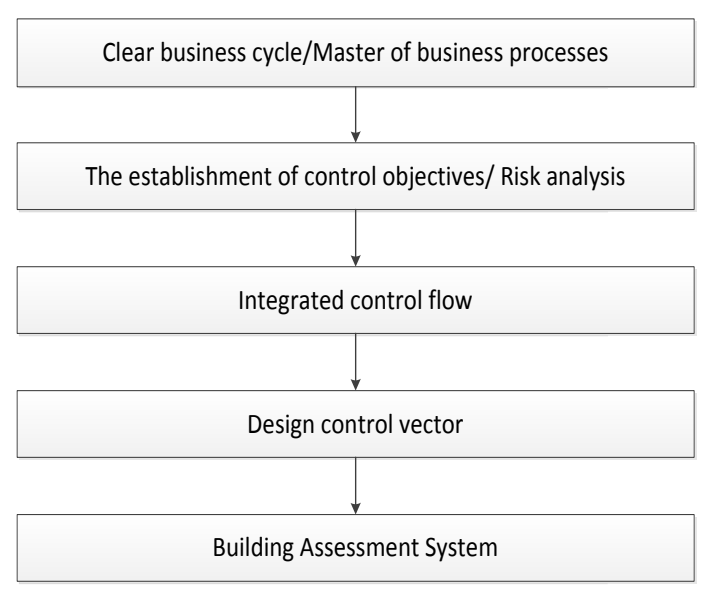

Fig.2: Design Procedure

The basic idea of internal accounting control system design is mainly make the aim of internal accounting controls as a guide to establish internal accounting control system; it mainly includes three aspects, and four key considerations, Three aspects include: internal accounting control of system accounting organizational structure and job settings, Internal accounting control system of accounting management and Internal accounting control system of accounting processes. Focus on four aspects to consider include the construction to business cycle model, the common business of the state, proposed internal accounting control points, determine the relevant control measures.

Specific to the internal accounting controls, with the widespread use of computers in the accounting, from the first generation accounting software to the current ERP system, this change proposed new requirements for the new accounting system of internal accounting controls.

First of all, we have to analyze the electronic accounting system structure, generally consists of accounting treatment subsystems, each subsystem and run the financial statements constitute accounting subsystems.

In accounting internal control design, we focus on the financial statements and accounting processing subsystem.

Due to the new challenges brought computer accounting system, we need to be adjusted in all aspects:

First, to establish a sufficiently powerful hardware platform.

Second, staffing is also very important, Staffing shown below: 


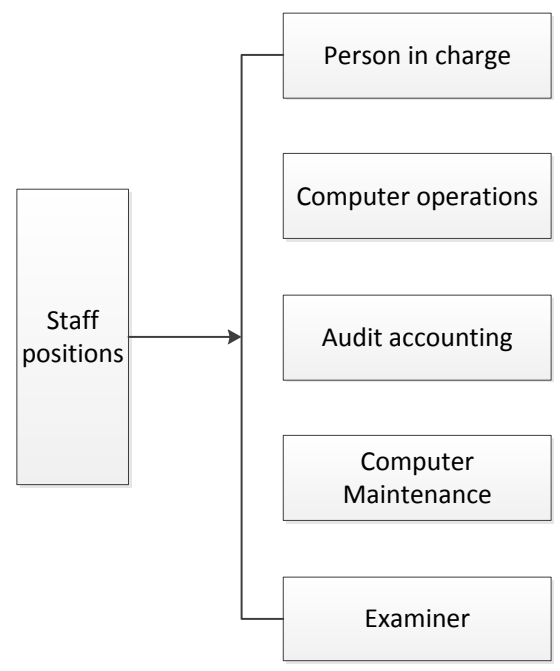

Fig.3: Staffing

Description control system description symbol before designing the control flow graph

\begin{tabular}{|c|c|c|c|}
\hline Symbol & Meaning & Symbol & Meaning \\
\hline & Flow line & & Books \\
\hline & Flow & & Card \\
\hline & Control Point & & 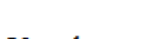 \\
\hline$---\gg<---$ & Check & & \\
\hline & File & & Retained \\
\hline
\end{tabular}

Fig.4: Symbol Description

Design of the internal control system, but also to set up a control point. They have to ensure that the role of the control objectives, and can prevent potential risks.

(1)Signing

Control Objectives: Ensure that the original documents on economic and business records of integrity, authenticity

(2)Check

Control Objectives: Ensure that the original documents in the form of legal, recording finished and metering compliance.

(3) Settle accounts

Control Objectives: Guarantee payment settlement is timely and accurate, cash management is secure

(4)Input Control

Control Objectives: Ensure that the input data is true and accurate.

(5)Repeat Check

Control Objectives: Ensure the temporary certificate is true and accurate.

(6)Embedded control

Control Objectives: Ensure that data processing is correct and efficient.

(7)Output Control

Control Objectives: Ensure that each output accounting accounts table is real and reasonable.

(8)Treasury management

Control Objectives: Ensure the safety of corporate assets, bank balance accurately grasp the situation.

Finally, system maintenance and security is also very important. System maintenance is a necessary condition to ensure system security, including hardware maintenance and software maintenance. Maintenance personnel need to have good computer operation, and require regular inspection system, system upgrades, make a record. 
The above analysis and design process, we have to show the internal accounting control system by the following map.

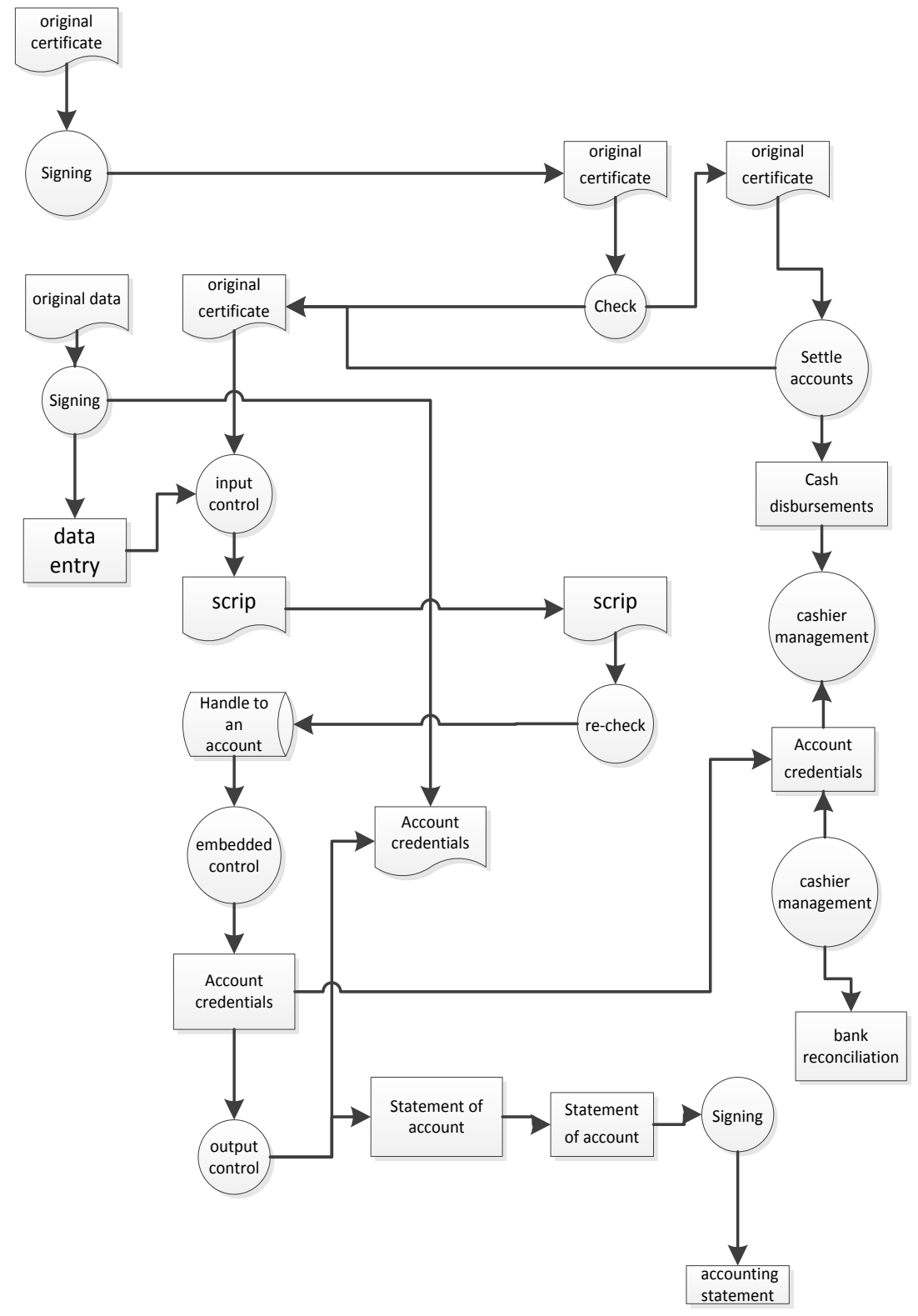

Fig .5: System Control Flow

\section{Conclusions}

By analyzing the principle of internal accounting control system, the general steps and design ideas and so on, the design of the internal accounting system on electronic accounting, it is important to enterprise accounting system.

\section{References}

[1] Wang Haibing, Yu Changchun. Information disclosure of internal control defects, and stakeholder's behavior research - based on a-share main board listed companies empirical evidence [J]. Journal of economics and management research, 2014, (5): p.69-75.

[2] Shi Yanxia. Introduction to the perfection of institution accounting internal control [J]. China's collective economy, 2014, (18):p. 122-123.

[3] Qiu-sheng wu, Ao Xiao-bo. Internal governance, internal control and debt governance effect -- 
empirical evidence from Chinese listed companies [J]. Journal of economic issues, 2014, (4): p.7580,129.

[4] Fan Hang-jian, Xiao Guang-hong. Theory of enterprise internal control concept of nature and reflect on [J]. Journal of accounting research, 2014, (2): p. 4-11.

[5] Lei Ying, Wu Jian-you, Sun Hong. The internal control auditing's influence on the quality of accounting surplus - based on the empirical analysis of the Shanghai a-share listed companies, [J]. Journal of accounting research, 2013, (11): p.75-81.

[6] Li Zhi-bing. Internal controls and environmental information disclosure -- empirical evidence from China's manufacturing listed companies [J]. China population resources and environment, 2014, 24(6):p. 77-83. DOI: 10. 3969/j.issn.1002-2104.2014.06.012.

[7] Zhao Libing, Zhang Ruiquan, zhi-hui yan. Accounting theory of internal control problems and solutions - the advantages of SaaS - online accounting service [J]. Modern economic information, 2014, (10): p.258-259.

[8] Li Zongyu. Analyses how to strengthen the public institution accounting internal control [J]. Journal of land bridge view, 2014, (10): p.72-73. 